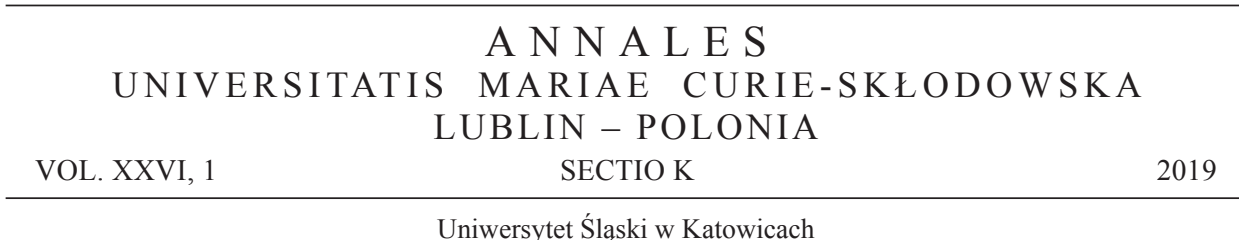

PATRYCJA ELŻBIETA SZOSTOK-NOWACKA

ORCID: https://orcid.org/0000-0002-2531-7237

\title{
Znaczenie poczucia podmiotowości dla aktywności społecznej w przestrzeni samorzadowej
}

The Importance of a Sense of Subjectivity for Social Activity in the Local Government

\begin{abstract}
ABSTRAKT
Artykuł jest prezentacją wyników kwestionariuszowych badań przeprowadzonych w zakresie komunikacji samorządowej, z uwzględnieniem poczucia podmiotowości komunikacyjnej obywateli oraz ich faktycznej aktywności w środowisku lokalnym. Opierając się na autorskiej koncepcji poczucia podmiotowości komunikacyjnej, dokonano jej weryfikacji w wywiadach kwestionariuszowych przeprowadzonych na 500 respondentach w województwie śląskim w 2016 roku. Celem badania było wykazanie, na ile poczucie podmiotowości, szczególnie tej komunikacyjnej, jest wyznacznikiem faktycznej aktywności obywateli w otoczeniu lokalnym. Główną hipotezę badania stanowiło przekonanie, że poczucie podmiotowości jest związane $\mathrm{z}$ aktywnością w przestrzeni samorządowej. W artykule zamieszczono wprowadzenie w tematykę, charakterystykę podmiotowości na poziomie lokalnym, zdefiniowano poczucie podmiotowości ogólnej i komunikacyjnej, zaprezentowano wyniki badań własnych dotyczących znaczenia poczucia podmiotowości komunikacyjnej dla aktywności obywatelskiej oraz sformułowano wnioski. Wyniki potwierdzają, że aktywność komunikacyjna koreluje z faktyczną aktywnością w otoczeniu lokalnym, szczególnie istotne są aspekty podmiotowości komunikacyjnej związane z komunikacją dwustronną. W badaniu wykazano, że poczucie podmiotowości komunikacyjnej nie jest wysokie, co pozwala w pewnym stopniu wnioskować nie tylko o powodach znikomej aktywności obywateli w środowisku lokalnym, ale także stwierdzić, że rozwój samorządowej działalności komunikacyjnej powinien przebiegać w kierunku zachęcania obywateli do aktywnego uczestnictwa $\mathrm{w}$ procesach porozumiewania się oraz budowania $\mathrm{w}$ nich uzasadnionego przekonania o ważności i przede wszystkim skuteczności tych działań.
\end{abstract}

Słowa kluczowe: aktywność społeczna, komunikacja samorządowa, partycypacja społeczna, podmiotowość komunikacyjna 


\section{WSTĘP}

Realizowany w Polsce model samorządu terytorialnego zakłada upodmiotowienie wspólnot lokalnych, które jednak w znacznym stopniu przejawia się wyłącznie w formalnoprawnym nadaniu podmiotowości owym wspólnotom, nie znajduje zaś odzwierciedlenia w faktycznej ich aktywności, co jest przesłanką do stwierdzenia, że istnieje rozdźwięk pomiędzy formalną podmiotowością wspólnot samorządowych a poczuciem podmiotowości samych obywateli. Choć poczucie możliwości wpływu na działania władz jest najwyższe właśnie na poziomie lokalnym [Krakowiak-Drzewiecka 2015: 59], badacze samorządności, jej praktycy, jak również autorzy realizowanej koncepcji samorządu terytorialnego wskazują, że podmiotowość wspólnot samorządowych nie jest realizowana w pełni. O rozdźwięku między założeniami transformacji ustrojowej a praktyką samorządu w tym zakresie oraz poziomem rozwoju społeczeństwa obywatelskiego w naszym kraju pisze się we współczesnych opracowaniach politologicznych, których autorzy wypowiadają się krytycznie, nie tylko oceniając dotychczasowe rozwiązania, ale również pozostają sceptyczni co do perspektyw dalszego rozwoju demokracji [Weryński 2015: 27; Turska-Kawa 2015: 141]. W związku z tym warto się zastanowić nad powodami niskiego poczucia podmiotowości wspólnot lokalnych i niezbyt wysokiego [Suwaj, Wenclik 2009: 373] udziału obywateli w zarządzaniu jednostkami samorządu terytorialnego. Ponieważ większość form partycypacji ma charakter de facto komunikacyjny, należy się zastanowić również nad komunikacyjnymi aspektami poczucia podmiotowości. Celem niniejszego artykułu jest w związku z powyższym wykazanie, na ile poczucie podmiotowości, szczególnie tej komunikacyjnej, jest wyznacznikiem faktycznej aktywności obywateli w otoczeniu lokalnym oraz zweryfikowanie hipotezy badawczej brzmiącej: ,poczucie podmiotowości jest związane $\mathrm{z}$ aktywnością w przestrzeni samorządowej”, jak również określenie, jakie aspekty owej podmiotowości w najwyższym stopniu determinują faktyczne działanie obywateli w środowisku lokalnym. Teoretyczne tło dla prowadzonych rozważań stanowi wiedza dotycząca prawnych, społecznych i psychologicznych aspektów podmiotowości i poczucia podmiotowości wspólnot lokalnych. Sama hipoteza zostanie zaś zweryfikowana na podstawie kwestionariuszowych badań dotyczących podmiotowego funkcjonowania w samorządzie terytorialnym, przeprowadzonych w 2016 roku na reprezentatywnej próbie 500 mieszkańców województwa śląskiego.

\section{PODMIOTOWOŚĆ SAMORZĄDU TERYTORIALNEGO}

Mówiąc o podmiotowości wspólnoty samorządowej, możemy mieć na myśli jej polityczno-prawne upodmiotowienie, jakie nastąpiło wraz z odrodzeniem samorządu terytorialnego w Polsce. Wtedy to jednostkom podziału terytorialnego nadano podmiotowość w tym znaczeniu, że „samorząd terytorialny nie jest jedynie 
formą decentralizacji władzy państwowej, dla jego wzmocnienia istotne znaczenie ma zaangażowanie mieszkańców w proces samoorganizacji i realizacji interesów grupowych" [Piasecki 2009: 31]. Mając na uwadze samą etymologię słowa „samorząd", możemy uznać, że podmiotowość jest wpisana w jego istotę i określenie „podmiotowość samorządu” potraktować jako sformułowanie tautologiczne [Kozłowski 2015: 41]. Podmiotowość ta jest jednak rozumiana przede wszystkim $\mathrm{w}$ sensie prawnym i politologicznym, a więc $\mathrm{w}$ wielu publikacjach jest sprowadzana do dwóch zasadniczych aspektów: świadomości i aktywności, to znaczy wiedzy na temat możliwości działania oraz jej praktycznego wykorzystania [Karwat 1980: 274; Jarosz 2015: 47]. Nieco szerzej postrzega to prawo Jerzy Regulski, który utrzymuje, że podstawą samorządności jest prawo, umiejętność i chęć działania [Regulski 2010: 15]. Szczególną wagę przywiązuje się tutaj do możliwości działania w sprawach, które bezpośrednio dotyczą danej jednostki, które stanowią punkt wyjścia do wszelkiej innej aktywności: „społeczeństwo obywatelskie jest oparte na idei, że każdy członek społeczności, bez względu na to, kim jest, jaką ważną rolę odgrywa w danej wspólnocie, ma prawo decydować o swoim losie i zabierać głos w sprawach, które go dotyczą" [Krzemiński 1992: 34]. Sama idea partycypacji społecznej opiera się na przekonaniu o dobrowolności nie tylko formy i zakresu podejmowanych działań, ale także samej aktywności (bądź jej zaniechania). Jak twierdził Giovanni Sartori, „uczestnictwo właściwie i sensownie rozumiane, polega na osobistym udziale, aktywnym i chętnym włączaniu się. Uczestnictwo nie jest więc prozaicznym byciem częścią czegoś, a tym bardziej niechcianym przymusowym włączeniem się do czegoś. Uczestnictwo to ruch samoistny, dokładne przeciwieństwo bycia włączonym w ruch (z cudzej woli), czyli przeciwieństwo zmobilizowania" [Sartori 1999: 148].

Mimo stworzenia ram prawnych dla upodmiotowienia wspólnot samorządowych i jej członków, w praktyce obywatele tylko w znikomym stopniu korzystają z możliwości aktywnego kształtowania otaczającej ich rzeczywistości. Ludzie nie tylko nie biorą aktywnego udziału w wydarzeniach dotyczących wspólnot lokalnych, ale również przejawiają znikome zainteresowanie kwestiami wykraczającymi poza ich życie osobiste i zawodowe [CBOS 2008, 2010]. Wśród teoretyków i badaczy samorządności w Polsce wskazuje się kilka najważniejszych grup przyczyn, dla których poziom rozwoju społeczeństwa obywatelskiego nie odpowiada założeniom transformacji ustrojowej [Weryński 2012: 27]. Oprócz niedoskonałości prawno-instytucjonalnych, szczególną uwagę zwraca się na społeczny aspekt samorządności, na fakt, że ludzie nie rozumieją, czym ona jest, nie doceniają jej wagi, nie potrafią dostrzec swoich realnych korzyści w interesie społecznym. Niewątpliwie wynika to z braków edukacyjnych, jak również z niedostatecznie silnych (a nawet osłabiających się) więzi społecznych [Regulski 2000: 58]. Człowiek, choć naturalnie stworzony jest do bycia podmiotem, aktualizuje tę podmiotowość i wzmacnia w procesie socjalizacji, dla której, zdaniem Anthony'ego Giddensa, konieczny jest taki kształt społeczeństwa, w którym owe potencjalne właściwości jednostek mogą się aktualizować, a więc stwarzający struktury właściwe dla realizacji owej podmiotowości [Giddens 2001: 17]. 
W związku z tym, że niezależnie od uwarunkowań prawno-instytucjonalnych partycypacja społeczna w Polsce pozostaje na niskim poziomie (o czym świadczy choćby udział Polaków w konsultacjach społecznych, budżecie partycypacyjnym czy przynależności do organizacji pozarządowych), przedmiotem zainteresowania w niniejszym opracowaniu będzie nie tyle sama podmiotowość wspólnot samorządowych (która jest obiektywna, uwarunkowania są identyczne dla wszystkich członków wspólnot samorządowych), co jej poczucie u poszczególnych obywateli. Celem stanie się odpowiedź na pytanie, na ile poszczególni obywatele czują się podmiotami, szczególnie w aspekcie komunikacyjnym, i jaki jest związek owego poczucia z realną aktywnością w przestrzeni samorządowej.

\section{POCZUCIE PODMIOTOWOŚCI I PODMIOTOWOŚCI KOMUNIKACYJNEJ}

Samą podmiotowość w rozumieniu politologicznym możemy zdefiniować jako zdolność jednostek lub grup do wywierania wpływu na otoczenie zewnętrzne przy jednoczesnej postawie zorientowanej na aktywne i świadome uczestnictwo w tym otoczeniu. Z perspektywy badawczej należałoby jednak posługiwać się raczej pojęciem ,poczucie podmiotowości”, a nie samej podmiotowości, z przynajmniej kilku powodów. Przede wszystkim podmiotowość człowieka jest kategorią, która nie podlega tutaj dyskusji, ponieważ z perspektywy aksjologicznej przysługuje ona wszystkim ludziom a priori, z perspektywy prawnej zaś została nadana wspólnotom samorządowym (i ich członkom) w równym stopniu. Nie jest więc zasadne szukanie odpowiedzi na pytanie, na ile ludzie są podmiotami, a jedynie o ich stopień poczucia owej podmiotowości, ewentualnie poziom jej realizacji. Po drugie, sama podmiotowość jest kategorią trudną do operacjonalizacji i badania ze względu na wiele czynników zewnętrznych i wewnętrznych, które się na nią składają. Zakładając więc, że mamy do czynienia z jednostkami funkcjonującymi w porównywalnych okolicznościach zewnętrznych (regulowanych przepisami prawa), możemy się zastanawiać, na ile w tych warunkach czują się oni podmiotami. Można badać same przejawy tej podmiotowości, przede wszystkim realną aktywność w środowisku samorządowym, jednak nie każda aktywność musi być związana z realną podmiotowością jednostki - działania mogą być podejmowane bez wiary w ich skuteczność, przynależność do organizacji może mieć znaczenie wyłącznie symboliczne lub wynikać z potrzeb afiliacyjnych, samo działanie zaś może być w różny sposób wymuszone (społecznie, administracyjnie itd.). Poczucie podmiotowości można, za Krzysztofem Korzeniowskim, definiować jako „poczucie, iż świadomie i opierając się na własnych wartościach jest się twórcą zdarzeń i stanów i/lub autorem znaczeń [...] Poczucie podmiotowości jest tym większe, w im większym stopniu działalność jednostki prowadzi do efektów zgodnych z jej oczekiwaniami sprawstwa czy autorstwa i w im większym stopniu są one jej osobistymi wartościami” [Korzeniowski 1983: 55-56]. 
Agnieszka Turska-Kawa zaproponowała, aby w badaniach nad podmiotowością polityczną posługiwać się trzema obszarami konstytuującymi jej poczucie (na kontinuum alienacja polityczna-podmiotowość): poczucie bezsilności-mocy; poczucie alienacji-samoznaczenia oraz poczucie izolacji-integracji [Turska-Kawa 2011: 162-163]. Na potrzeby niniejszego opracowania, opierając się na doświadczeniach innych badaczy, dokonano operacjonalizacji poczucia podmiotowości w sześciu wymiarach: poczucie sprawstwa i wpływu, niezależność od otoczenia, zakotwiczenie we wspólnocie (identyfikacja ze środowiskiem lokalnym), poczucie bycia szanowanym członkiem społeczności, poczucie eunomii (zgodności własnego systemu wartości z otaczającym światem), możliwość samorealizacji, poczucie sprawiedliwości społecznej oraz poczucie bezpieczeństwa [Szostok 2017: 322].

W rozważaniach dotyczących aktywności obywatelskiej na poziomie lokalnym (i nie tylko) podmiotowość człowieka można również rozważać przez pryzmat aspektów komunikacyjnych z przynajmniej dwóch powodów. Po pierwsze, podstawą każdej aktywności musi być wiedza na temat jej przedmiotu, możliwych sposobów, kierunków, jak również konsekwencji działania [Urban 2008: 93]. Aktywność nie opartą na wystarczających poznawczych (uwzględniających również dostęp do bieżących informacji) komponentach należy uznać za chaotyczną, przypadkową i niezależną od świadomych decyzji jednostki, a więc nie podmiotową. Po drugie, partycypacja społeczna na poziomie lokalnym przybiera głównie postać działań komunikacyjnych [Sura, Choma 2014: 145], więc zasadne jest poszukiwanie odpowiedzi na pytanie o stan owej partycypacji właśnie we wskaźnikach związanych z poczuciem komunikacyjnej podmiotowości.

Podmiotowość komunikacyjna pojawia się w refleksji naukowej dość rzadko, co nie oznacza, że jej odpowiedniki są pomijane w koncepcjach podmiotowości ogólnej, w których zwraca się uwagę na przykład na element kompetencji poznawczej [Cichocki 2003: 137] czy też na komunikacyjne aspekty podmiotowej relacji człowieka z otoczeniem [Nowak 2011: 90]. Uwaga jest zwracana również na to, że wraz z rozwojem środków masowego komunikowania zmienia się rola nadawcy i odbiorcy w tym kierunku, że ten ostatni, dzięki możliwości interaktywnego kontaktu, jaką dają media internetowe, zyskuje podmiotowość w relacji z instytucjami nadawczymi [Miczka-Pajestka 2005: 107].

Biorąc pod uwagę opinie teoretyków podmiotowości jako takiej oraz tych, którzy odnosili się do jej komunikacyjnego aspektu, podmiotowość komunikacyjną można zdefiniować jako ,szereg uwarunkowań, które składają się na poznawczą aktywność jednostki, dając jej przekonanie, że nie tylko ma prawo domagać się informacji i zdobywać je na własną rękę, ale również wypowiadać się z uzasadnionym przekonaniem, że wypowiedzi te są skuteczne, to znaczy mają moc sprawczą w otoczeniu" [Szostok 2017: 356]. Na tak zdefiniowaną podmiotowość komunikacyjną składają się następujące elementy: poczucie poinformowania o wydarzeniach w otoczeniu lokalnym, w szczególności o tym, co bezpośrednio dotyczy danej osoby; aktywność w procesie komunikowania lokalnego; przekonanie, że wyrażane zdanie jest brane 
pod uwagę przez władze; poczucie dysponowania zasobem wiedzy umożliwiającym efektywne działanie oraz nieskrępowane wyrażanie własnego zdania.

Dla realizacji partycypacyjnego modelu samorządności czy też szerzej - budowy społeczeństwa obywatelskiego, procesy komunikacyjne są bardzo istotne. Możliwości technologiczne są w tym względzie coraz szersze, interaktywność komunikowania internetowego skłania wielu badaczy mediów do rozważań nad zmianą postrzegania tradycyjnych ról komunikacyjnych, wniosków o równouprawnieniu lub choćby zwiększeniu symetrii w tych procesach [Demczuk 2004: 496]. Na poziomie ustawodawczym również zwraca się uwagę na znaczenie informacji (czy szerzej - komunikacji) dla sprawnego funkcjonowania administracji i realizowania praw obywatelskich, wprowadzając kolejne regulacje dotyczące dostępu do informacji publicznej, wdrażając e-administrację itd. W samych samorządach terytorialnych również podejmowane są liczne działania, zmierzające do jak najlepszego realizowania zadań komunikacyjnych, które wychodzą często poza ustawowe obowiązki przekazywania informacji publicznej, wdraża się strategie komunikacyjne, tworzy specjalne wydziały, powołuje rzeczników prasowych, przygotowuje własne media [Olejniczak-Szałowska 2014: 754].

Od początku lat 90. XX wieku podmiotowość wspólnot lokalnych jest przedmiotem badań prowadzonych przez CBOS, przy czym jest ona rozumiana dość wąsko jako poczucie indywidualnego wpływu na sytuację lokalną. Tuż po odrodzeniu samorządu terytorialnego w Polsce owo poczucie było dość znikome, zaledwie 16\% obywateli deklarowało, że posiada taki wpływ na sytuację w najbliższym otoczeniu. W roku 2010 odsetek pozytywnych odpowiedzi na tak zadane pytanie wyniósł 52\% [CBOS 2015: 1]. Od tego czasu utrzymuje się na względnie stałym poziomie (49\%). Połowa osób badanych czuje się podmiotami, co, być może, nie jest wynikiem wysokim, jednak jest on na poziomie lokalnym znacznie wyższy niż poczucie wpływu na sytuację w kraju, w przypadku której zaledwie co czwarty ankietowany posiada takie poczucie [CBOS 2015: 2]. Samo przekonanie o możliwości wpływu na otoczenie lokalne nie jest tożsame ze wskaźnikami rozwoju społeczeństwa obywatelskiego, które, zdaniem Agnieszki Turskiej-Kawy, się obniżają [Turska-Kawa 2015: 141].

\section{ZNACZENIE POCZUCIA PODMIOTOWOŚCI DLA AKTYWNOŚCI OBYWATELSKIEJ - WYNIKI BADAŃ WŁASNYCH}

Głównym celem przeprowadzonego badania było wykazanie, na ile poczucie podmiotowości, szczególnie tej komunikacyjnej, jest wyznacznikiem faktycznej aktywności obywateli w otoczeniu lokalnym. Na potrzeby projektu sformułowano podstawową hipotezę, że ,poczucie podmiotowości jest związane z aktywnością w przestrzeni samorządowej". Tak sformułowana hipoteza jest efektem refleksji dotyczącej rozbieżności pomiędzy możliwościami aktywnego uczestnictwa w kształtowaniu polityki lokalnej a realną aktywnością obywateli na poziomie lokalnym. 
Podejrzewa się więc, że mimo obiektywnych uwarunkowań obywatele nie czują się podmiotami, w związku z czym nie podejmują aktywności. I - odpowiednio - że osoby, które czują się podmiotami, aktywność taką podejmują chętniej. Punktem wyjścia do wnioskowania w niniejszym opracowaniu są badania przeprowadzone w pierwszym kwartale 2016 roku w województwie śląskim. Ich podstawą stało się przekonanie, że poczucie podmiotowości obywateli pozwala wnioskować o ich potencjale partycypacyjnym, przy czym pod uwagę wzięto nie tylko poczucie podmiotowości ogólnej, ale również komunikacyjnej. Samym badaniem objęto aspekty poczucia podmiotowości, omówione wcześniej w artykule, które są w jakiś sposób zależne od czynników zewnętrznych, nie zaś będące wynikiem osobistych uwarunkowań jednostki (jak na przykład umiejscowienie kontroli wzmocnień czy samoocena).

Techniką zastosowaną w badaniu był wywiad kwestionariuszowy. O wyborze sposobu przeprowadzenia badań zadecydowała relatywna łatwość jego realizacji oraz możliwość powtórzenia $\mathrm{w}$ innych przestrzeniach komunikacyjnych (nie tylko na innym terytorium, ale także, po pewnej modyfikacji narzędzia, w innych zbiorowościach, np. organizacyjnych). Dodatkowym atutem tej techniki jest również możliwość zgromadzenia dużej ilości danych, co dla wnioskowania o zależnościach istotnych statystycznie ma kluczowe znaczenie. Niewątpliwym mankamentem jest z kolei brak możliwości manipulowania zmiennymi, co powoduje brak podstaw do wnioskowania o kierunku stwierdzonych zależności [Wimmer, Dominick 2008: 251-252]. Na potrzeby badania skonstruowano autorski kwestionariusz, dokładając wszelkich starań, aby jego pytania były zgodne z celem badania oraz zrozumiałe dla potencjalnych respondentów [Dobek-Ostrowska, Sobera 2017: 20]. Aby zmaksymalizować jego adekwatność do celu badania, poddano go najpierw ocenie przez sędziów kompetentnych (głównie pracowników naukowych zajmujących się komunikowaniem lokalnym i socjologią miasta, ale także dziennikarzy mediów lokalnych i pracowników jednostek samorządowych), następnie zaś przeprowadzono badania pilotażowe, obejmujące 20 respondentów. Ostatecznie kwestionariusz składał się z 30 pytań (otwartych, zamkniętych i półotwartych, w większości w postaci wieloczłonowej alternatywy lub skali), zgrupowanych w czterech zasadniczych dla badania kategoriach: sposoby komunikowania w przestrzeni lokalnej, aktywność obywatelska, poczucie podmiotowości ogólnej oraz poczucie podmiotowości komunikacyjnej.

Badania przeprowadzono w województwie śląskim na próbie 500 mieszkańców, której struktura wieku i płci była reprezentatywna dla populacji województwa. Dobór próby był celowo-losowy, co w tym przypadku oznacza, że przeprowadzono po 100 wywiadów w 5 grupach miejscowości, które wyodrębniono na podstawie ustalonych w badaniu z 2011 roku sposobów komunikowania się jednostek samorządowych [Szostok, Rajczyk 2013]. W grupie miejscowości komunikujących się zgodnie z wynikami ówczesnego badania najsłabiej znalazły się więc gminy: Ślemień, Istebna, Kruszyna, Milówka, Radziechowy-Wieprz, Wielowieś i Dąbrowa Zielona; w grupie komunikujących się słabo: Mysłowice, Siemianowice Śląskie, Lędziny, Rajcza, Strumień, Tarnowskie Góry i Świerklaniec; w grupie komunikujących się średnio: 
Jaworzno, Gierałtowice, Godów, Krupski Młyn, Mszana, Łaziska Górne, Kamienica Polska; komunikujących się dobrze: Chorzów, Świętochłowice, Tychy, Wisła, Pszczyna i Katowice; komunikujących się bardzo dobrze: Częstochowa, Gliwice, Sosnowiec, Jastrzębie-Zdrój, Racibórz, Wodzisław Śląski i Bielsko-Biała. Wywiady przeprowadzali przeszkoleni wcześniej ankieterzy, którzy za swoją pracę otrzymali wynagrodzenie. Następnie wyniki zakodowano w programie SPSS i poddano analizie statystycznej, podstawą wnioskowania są przede wszystkim testy korelacji.

Uzyskane wyniki badań, zaprezentowane na wykresie 1, pozwalają stwierdzić, że poczucie podmiotowości wynosi średnio poniżej 3 punktów w 5 -punktowej ${ }^{1}$ skali, co oznacza, że respondenci czują się podmiotami w stopniu średnim. Wśród wymiarów podmiotowości, które są oceniane najniżej, znalazł się nonkonformizm rozumiany jako wyrażanie kontrowersyjnego zdania bez obawy o konsekwencje w otoczeniu lokalnym, natomiast najwyższy wynik uzyskano w kategorii okazywania szacunku przez władze i urzędników. Jest to niewątpliwie efekt zmian w świadomości pracowników samorządowych i postrzegania mieszkańców nie w kategorii petentów, a klientów czy nawet partnerów działania.

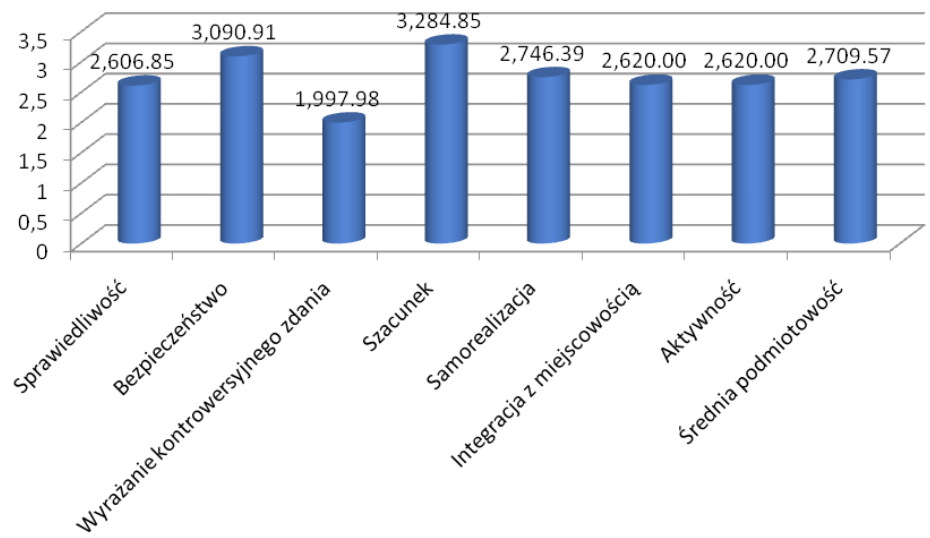

Wykres 1. Poczucie podmiotowości na poziomie lokalnym i jego poszczególne składowe.

Opracowanie własne. $\mathrm{N}=500$.

Z przeprowadzonych badań wynika również, że poziom podmiotowości komunikacyjnej jest raczej niski, w 5-punktowej skali wynosi tylko 2,54. Jak zaprezentowano na wykresie 2 , zaledwie $45 \%$ respondentów posiada poczucie komunikacyjnej

1 Ocen poszczególnych stwierdzeń diagnostycznych dokonywano za pomocą 5-punktowej skali, gdzie 1 oznaczał zupełny brak zgody, natomiast 5 - całkowitą identyfikację z twierdzeniami kwestionariusza. Prezentowane są wyniki średnie uzyskane w badanej próbie. Odpowiednio więc uzyskane wyniki należy interpretować: 1 - znikome poczucie podmiotowości, 2 - niskie poczucie podmiotowości, 3 - średnie poczucie podmiotowości, 4 - wysokie poczucie podmiotowości, 5 - pełne poczucie podmiotowości. 
podmiotowości na poziomie średnim lub wyższym, czyli takim, który można uznać za stwarzający podstawę dla ich aktywności w środowisku lokalnym.

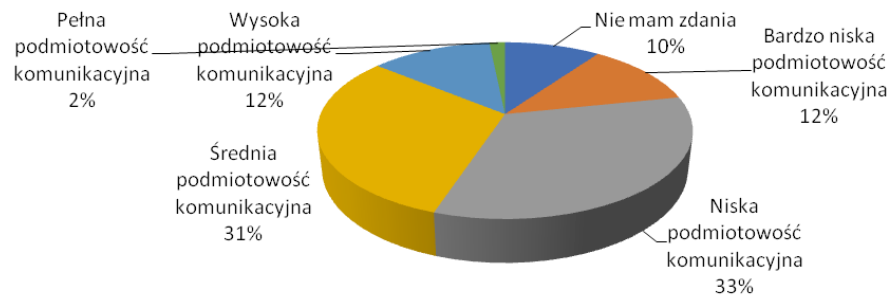

Wykres 2. Poczucie podmiotowości komunikacyjnej na poziomie lokalnym.

Opracowanie własne. $\mathrm{N}=500$.

Wśród czynników składających się na podmiotowość komunikacyjną w otoczeniu samorządowym żaden nie został oceniony przez respondentów jako wysoki lub bardzo wysoki. Na podstawie wyników zaprezentowanych na wykresie 3 możemy jednak stwierdzić, że poczucie poinformowania o sprawach lokalnych oraz poczucie poinformowania o kwestiach indywidualnie ważnych osiągają poziom średni, co oznacza, że wysiłki władz samorządowych (i nie tylko) ukierunkowane na przekazywanie informacji są dostrzegane, przynajmniej w aspekcie ilościowym dostarczanie informacji na poziomie lokalnym odbywa się sprawnie. Obywatele nie potrafią jednak znaleźć praktycznego zastosowania dla otrzymywanych informacji, nie są przekonani, że są im one do czegoś przydatne, ponieważ ocena praktycznego poinformowania (posiadania wystarczającej ilości informacji do działania) jest niższa. Nie odczuwają również potrzeby aktywnego zdobywania informacji, nie podejmują inicjatywy komunikacyjnej w środowisku lokalnym, co potwierdza tezę o małej świadomości praktycznego znaczenia informacji o najbliższym otoczeniu. Podejmowanie aktywności komunikacyjnej jest niskie również ze względu na brak przekonania o tym, że może ona być skuteczna. Osoby badane są pewne, że władze nie biorą ich zdania pod uwagę, a jeśli to czynią, to bardzo rzadko i w ograniczonym zakresie.

Próbując zrekonstruować poczucie podmiotowości komunikacyjnej członka wspólnoty samorządowej, możemy stwierdzić, że przeciętnie jest to osoba, która czuje się dość dobrze poinformowana o tym, co się dzieje wokół niej, szczególnie o sprawach bezpośrednio jej dotyczących, jednak nie przejawia aktywności w poszukiwaniu informacji, a więc zadowala się tym, co zostaje jej przekazane. Informacje nie są postrzegane jako podstawa aktywności, nie mają więc funkcji utylitarnej. Dialog wydaje się mało możliwy, gdyż osoba taka co prawda wyraża czasem (raczej rzadko) swoje zdanie, ale nie wierzy w jego skuteczność, jest przekonana, że prawie nigdy nie jest ono brane pod uwagę przez władze. 


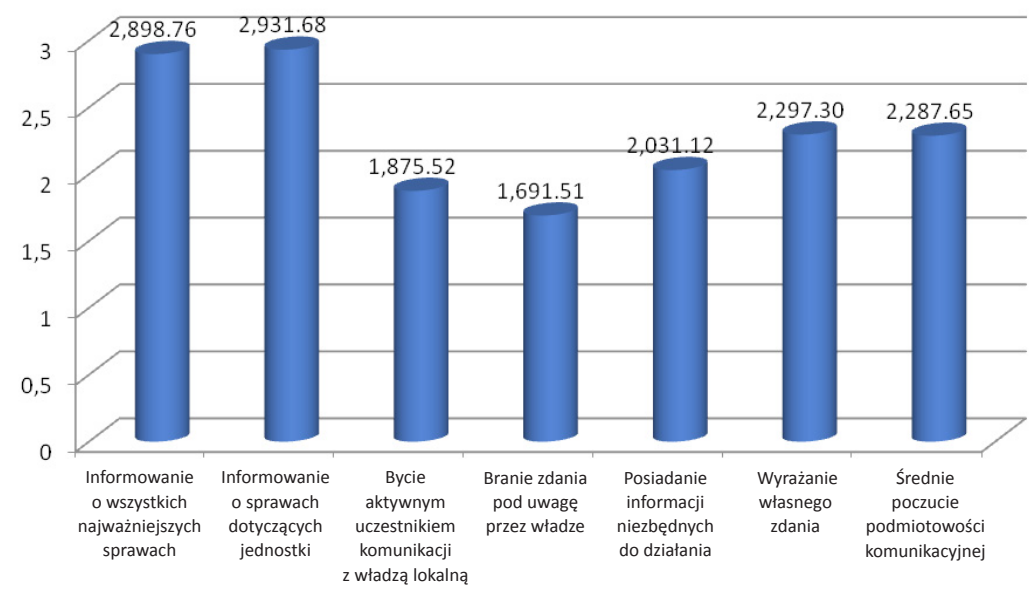

Wykres 3. Poczucie podmiotowości komunikacyjnej na poziomie lokalnym i jego poszczególne wymiary.

Opracowanie własne. $\mathrm{N}=500$.

Podmiotowość komunikacyjna nie jest związana z wiekiem (korelacja na poziomie $\mathrm{R}=0,009)$, udało się jednak ustalić słabą korelację z poczuciem związku z miejscem zamieszkania $(\mathrm{R}=0,231)$. Co ciekawe, związek poczucia podmiotowości komunikacyjnej z poziomem komunikacyjnym jednostki (określonym na podstawie ilości i różnorodności używanych narzędzi komunikowania) również nie jest wysoki, zależność ta okazała się mniej istotna od poczucia związku z miejscowością (współczynnik korelacji $\mathrm{R}=0,153$ ).

Na podstawie uzyskanych w badaniu wyników można stwierdzić, że członkowie badanych społeczności tylko w niewielkim stopniu czują się podmiotami w komunikacji z przedstawicielami lokalnych władz i - szerzej - administracji samorządowej. W badaniu zweryfikowano także poziom aktywności obywateli w przestrzeni samorządowej. Oczywiście wnioskowanie opiera się wyłącznie na deklaracjach respondentów, nie zaś na obiektywnych danych potwierdzających tę aktywność. Osoby badane zapytano o następujące przejawy działania w otoczeniu lokalnym: udział w wyborach lokalnych, niewymuszone wyrażanie własnego zdania, postawa wobec aktywności obywatelskiej, uczestnictwo w wyborach lokalnych, znajomość metod działania w środowisku lokalnym, świadomość możliwości i instrumentów działania, przynależność do organizacji oraz udział (również w charakterze autora projektu) w budżecie obywatelskim. Każde pytanie było punktowane osobno, następnie wyniki zsumowano. Wynikom zbiorczym nadano rangi odpowiadające minimalnej, niewielkiej, średniej, dużej i bardzo dużej aktywności. Warto dodać, że średni wynik surowy w 14-punktowej skali wyniósł 6,8 punktu, co odpowiada średniemu poziomowi aktywności. Zgodnie z wynikami badań, zaprezentowanymi na wykresie 4 , średni poziom aktywności okazał się charakterystyczny dla nieco więcej niż co trzeciego respondenta, podobny odsetek zadeklarował aktywność niewielką. Mniej niż co piąty badany charakteryzuje się dużą lub bardzo dużą aktywnością w otoczeniu lokalnym. 


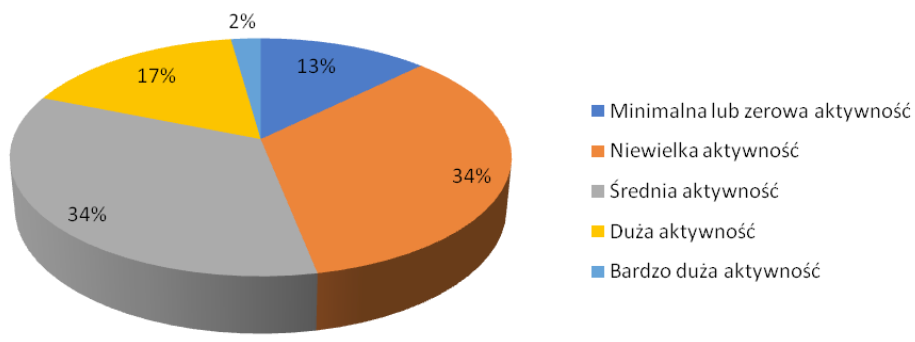

Wykres 4. Aktywność obywatelska w przestrzeni samorządowej.

Opracowanie własne. $\mathrm{N}=500$.

Konfrontując uzyskane dane na temat poczucia podmiotowości oraz aktywności obywatelskiej, uzyskano potwierdzenie wzajemnej zależności. Ustalono, że w przypadku poczucia podmiotowości ogólnej korelacja z wymiarem aktywności wynosi $\mathrm{R}=302$, w przypadku poczucia podmiotowości komunikacyjnej współczynnik korelacji z wymiarem aktywności wyniósł $\mathrm{R}=320$. Stwierdzono, że spośród wszystkich elementów składowych poczucia podmiotowości komunikacyjnej z aktywnością obywatelską na poziomie lokalnym największy związek istnieje w przypadku czynnika dotyczącego wyrażania własnego zdania $(\mathrm{R}=336)$, natomiast wśród wymiarów podmiotowości ogólnej z aktywnością lokalną w najwyższym stopniu koreluje nonkonformizm rozumiany jako wyrażanie kontrowersyjnego zdania bez obawy o konsekwencje w środowisku lokalnym $(\mathrm{R}=365)$ [szerzej na ten temat: Szostok 2017: 400-401]. Aktywność społeczna ma więc związek z aktywnością komunikacyjną - taką, która jest postrzegana jako skuteczna i bezpieczna, jednak polega nie tylko na niezakłóconym gromadzeniu informacji, ale również (a może przede wszystkim) na nieskrępowanym wypowiadaniu własnego zdania. Jak wykazano wcześniej, czynnik ten, co prawda, nie jest najsłabszym elementem poczucia podmiotowości komunikacyjnej w badanych społecznościach, jednak jego średnie natężenie wynosi 2,3 punktu, co oznacza, że oceniany jest jako raczej słabo charakteryzujący osoby badane.

W kontekście przyjętych ustaleń warto przyjrzeć się komunikacyjnym zachowaniom tych osób, które w badaniu uzyskały wysokie lub bardzo wysokie wyniki w wymiarze poczucia podmiotowości komunikacyjnej w przestrzeni lokalnej. Uzyskane wyniki badań pozwalają na stwierdzenie pewnych prawidłowości w tym zakresie.

Jak wynika z danych zaprezentowanych na wykresie 5, widoczne są różnice dotyczące źródeł informacji na temat wydarzeń w najbliższym otoczeniu, jakie preferują osoby charakteryzujące się różnym poziomem analizowanego czynnika. I tak, osoby o wysokim lub bardzo wysokim poziomie poczucia komunikacyjnej podmiotowości znacznie częściej wskazują jako źródło informacji lokalnej prasę oraz internet, podczas gdy dla pozostałych grup bazą taką najczęściej pozostają rozmowy z innymi ludźmi, a więc źródło najbardziej narażone na powstawanie plotek i stosunkowo najmniej wiarygodne. Prasa lokalna czy internet wymagają jednak 
od swoich użytkowników pewnej aktywności, wysiłku włożonego w pozyskiwanie informacji, podczas gdy rozmowy z innymi ludźmi nie są tym obostrzone. Warto zwrócić uwagę, że tylko w grupie o najwyższym poziomie analizowanego wskaźnika wśród źródeł informacji znalazły się rozmowy z przedstawicielami lokalnych władz, co może świadczyć, z jednej strony, o dużej determinacji jej przedstawicieli do pozyskiwania informacji, ale również o tym, że tam, gdzie takie kontakty są dostępne, stwarzane są warunki do kształtowania poczucia podmiotowości komunikacyjnej.

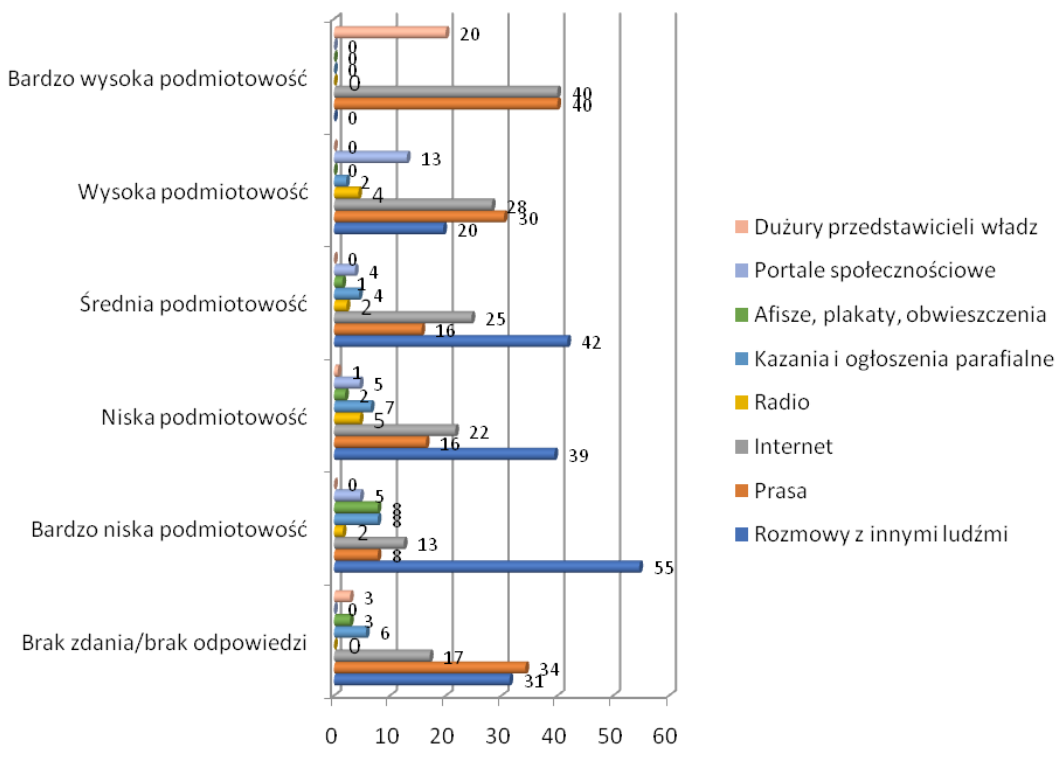

Wykres 5. Poczucie podmiotowości komunikacyjnej a najważniejsze źródło informacji lokalnej.

Opracowanie własne. $\mathrm{N}=500$.

Osoby o wysokim i bardzo wysokim poziomie poczucia podmiotowości komunikacyjnej różnią się od pozostałych uczestników badania również postrzeganiem tego, jakich źródeł informacji brakuje w ich najbliższym otoczeniu. Wykazano (wykres 6), że im wyższy poziom tego wskaźnika, tym większe znaczenie jest nadawane prasie lokalnej, na której deficyt wskazywały najczęściej osoby o największym poziomie poczucia podmiotowości, podczas gdy w pozostałych grupach większą uwagę zwracano na brak mediów elektronicznych, w szczególności radia i telewizji, co może świadczyć o różnych potrzebach charakteryzujących te grupy. Co ciekawe, grupy o wysokim poziomie poczucia podmiotowości komunikacyjnej relatywnie rzadziej wskazywały na brak kontaktów bezpośrednich z władzami, co w kontekście poprzednich ustaleń należy uznać nie tyle za przejaw niskiej rangi nadawanej temu właśnie źródłu, co raczej znajomości sposobów realizacji takich kontaktów. 


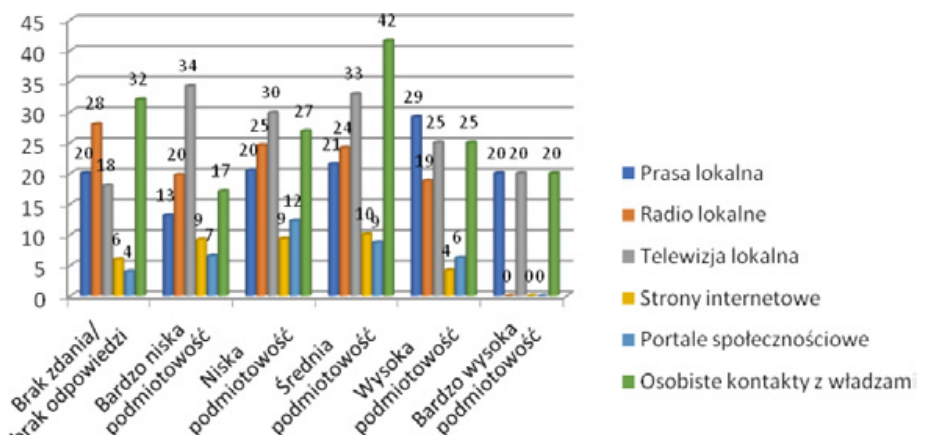

Wykres 6. Braki źródeł informacji lokalnej a poczucie podmiotowości komunikacyjnej na poziomie lokalnym.

Opracowanie własne. $\mathrm{N}=500$.

Poziom poczucia podmiotowości komunikacyjnej skonfrontowano także z oceną działań komunikacyjnych podejmowanych przez władze ${ }^{2}$. Również w tym przypadku okazało się (wykres 7), że istnieje zależność - osoby o wysokim poziomie poczucia podmiotowości komunikacyjnej wyżej oceniają działania władz zmierzające do poznania zdania obywateli niż respondenci o niskim poziomie owego wskaźnika. Odnosząc te wyniki do wcześniejszych ustaleń dotyczących znaczenia wypowiadania swojego zdania dla aktywności obywatelskiej, należy stwierdzić, że wymiar ten jest bardzo istotny nie tylko dla poczucia podmiotowości, ale również dla aktywności obywatelskiej jako takiej.

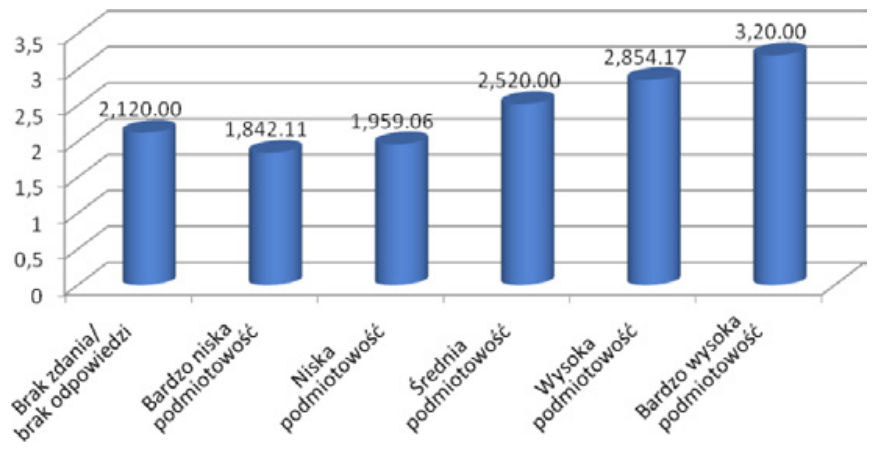

Wykres 7. Ocena aktywności komunikacyjnej władz w grupach o różnym poziomie poczucia podmiotowości komunikacyjnej.

Opracowanie własne. $\mathrm{N}=500$.

2 W skład owej oceny weszły takie czynniki, jak: pytanie obywateli o zdanie, tematy i formy konsultacji społecznych, podawanie ich wyników do publicznej wiadomości oraz uwzględnianie ich w procesach decyzyjnych. 


\section{ZAKOŃCZENIE}

Zaprezentowane wyniki badań pozwalają na pozytywne zweryfikowanie hipotezy badawczej i potwierdzenie, że poczucie podmiotowości jest związane z aktywnością w przestrzeni samorządowej. Szczególne znaczenie zaś dla obu badanych wymiarów ma możliwość wyrażania własnego zdania - zarówno spontanicznego, jak i inicjowanego przez władze samorządowe. Sam poziom poczucia owej podmiotowości waha się pomiędzy słabym a średnim, co, być może, jest związane także z osobowościowymi uwarunkowaniami osób badanych, jednak przynajmniej częściowo jest on zależny również od okoliczności, w jakich odbywa się komunikacja samorządowa. Skoro stwierdzono, że poczucie podmiotowości koreluje z aktywnością na poziomie lokalnym, mimo braku możliwości określenia kierunków tej zależności, można sformułować kilka wniosków (uwag) dotyczących komunikowania samorządowego, które nasuwają się na podstawie analizy poszczególnych czynników wchodzących w skład poczucia podmiotowości komunikacyjnej.

- Informowanie jest tą sferą komunikowania, która jest realizowana w sposób najlepszy. Niewątpliwie wykorzystuje się wiele instrumentów docierania do obywateli z informacją, szczególnie tą, która jest dla nich ważna indywidualnie. Jednak informacje te nie są postrzegane jako przydatne, mieszkańcy zazwyczaj nie potrafią docenić ich utylitarnego znaczenia, wykorzystać dla poprawy swojej skuteczności. Możliwe, że przekazywane informacje, mimo swej ilości nie są właściwie dobierane lub nie wskazuje się ich utylitarnych dla odbiorców aspektów.

- Obywatele pozostają pasywni w procesach komunikowania samorządowego, nie wykazują inicjatywy w poszukiwaniu informacji, nie zadają pytań, dlatego ważne są wysiłki zmierzające do jak najpełniejszego informowania mieszkańców o tym, co się dzieje, jak również te ukierunkowane na edukowanie obywateli w kwestii znaczenia informacji o najbliższym otoczeniu. Edukacja jest ważna nie tylko dla kształtowania postaw obywatelskich na poziomie lokalnym, ale również dla budowy tak zwanego społeczeństwa obywatelskiego w ogóle, samej partycypacji przypisuje się zresztą funkcje edukacyjne w tym zakresie [Swianiewicz 2012: 36].

- Działania ukierunkowane na poznanie opinii obywateli są bardzo ważne z perspektywy zarówno poczucia podmiotowości komunikacyjnej, jak i faktycznej aktywności w przestrzeni lokalnej. Oprócz samego procesu gromadzenia owych opinii, istotne jest również podawanie ich wyników do publicznej wiadomości, jak również informowanie o sposobach uwzględnienia ich w procesach decyzyjnych.

- Wykazano, że z aktywnością społeczną korelują w najwyższym stopniu te aspekty komunikacji, które są oparte na spontanicznym wyrażaniu własnego zdania. Dostępność kanałów wyrażania opinii to tylko jeden z czynników mogących wpływać na przejawianie tego typu aktywności, inne to poczucie 
bezpieczeństwa związane z wyrażaniem zdania oraz włączanie się przedstawicieli władz w tego rodzaju wymianę zdań.

- Szczególne znaczenie dla budowania dialogu społecznego na poziomie lokalnym (i nie tylko) ma komunikacja internetowa, która stwarza wiele możliwości kontaktu interaktywnego, które jednak, z różnych powodów, są wykorzystywane w znikomym stopniu [Parnes 2015: 121].

Poziom lokalny i istniejące struktury samorządu terytorialnego są tą przestrzenią, gdzie najpełniej może się realizować partycypacja społeczna i gdzie największe szanse rozwoju ma społeczeństwo obywatelskie [Wódz 2004: 229], dlatego zgodnie z opinią wielu uczonych szczególnie ważna jest na tym poziomie skuteczna, dwustronna, uwzględniająca wszelkie kanały komunikacja [Regulski 2013: 9]. W związku z zanikiem tradycyjnie rozumianych więzi lokalnych, poczucia wspólnoty badacze wskazują na konieczność podejmowania działań zmierzających do ich wytworzenia na podstawie czynników, niewynikających z tradycji wspólnego zamieszkiwania na danym terytorium od pokoleń. Jak stwierdził Zygmunt Bauman, tożsamość lokalna nie jest już ,»dana« lecz »zadana«. [...] z odkryciem tożsamości przychodzi na świat »podmiotowość refleksyjna«" [Bauman 2004: 29], potrzeba więc czegoś, co stanie się podstawą kształtowania nowego rodzaju wspólnot lokalnych. Wspólnoty te są obecnie budowane na podstawie bardziej subiektywnych niż więzy krwi czy tradycyjne zamieszkiwanie na danym terenie kryteriów [Starosta 2012: 228]. Takim czynnikiem może być dobrze pojmowany wspólny interes, który prawidłowo komunikowany i postrzegany jako możliwy do zrealizowania może się stać podstawą do podejmowania aktywności na poziomie samorządu terytorialnego. Omówiona kategoria poczucia podmiotowości, w tym również komunikacyjnej, jest jednym z czynników mogących wpływać na realną aktywność w środowisku lokalnym. Z perspektywy badawczej można więc rozszerzyć empiryczne poszukiwania w zakresie komunikowania lokalnego właśnie o kategorię poczucia podmiotowości komunikacyjnej, która w świetle już przeprowadzonych badań daje szersze możliwości rozumienia skuteczności działań komunikacyjnych podejmowanych w przestrzeni samorządowej.

\section{BIBLIOGRAFIA}

Bauman, Z. 2004. O tarapatach tożsamości w ciasnym świecie, [w:] Dylematy wielokulturowości, W. Kalaga (red.), Universitas, Kraków, s. 13-39.

CBOS, 2004. Spoleczeństwo obywatelskie 1998-2004, Warszawa.

CBOS, 2008. Poczucie wptywu na sprawy publiczne, Warszawa.

CBOS, 2010. Aktywność Polaków w organizacjach obywatelskich w latach 1998-2010, Warszawa.

Cichocki, R. 2003. Podmiotowość w społeczeństwie, Wydawnictwo Naukowe UAM, Poznań.

Demczuk, A. 2004. Polityka informacyjna gmin i powiatów Lubelszczyzny, [w:] Samorzad lokalny w Polsce. Społeczno-polityczne aspekty funkcjonowania, S. Michałowski (red.), Wydawnictwo UMCS, Lublin, s. 488-502. 
Dobek-Ostrowska, B., Sobera, W. 2017. Rola metod badawczych w studiach komunikologicznych, [w:] Badania ilościowe i jakościowe w studiach nad komunikowaniem, B. Dobek-Ostrowska, R. Sobera (red.), Wydawnictwo Uniwersytetu Wrocławskiego, Wrocław, s. 19-31.

Giddens, A. 2001. Nowe zasady myśli socjologicznej, Nomos, Kraków.

Jarosz, A. 2015. Samorząd miejski jako sfera podmiotów publicznych w procesie transformacji ustrojowej Rostock i Toruń w ujęciu porównawczym, Wydawnictwo Adam Marszałek, Torun.

Karwat, M. 1980. Podmiotowość polityczna: humanistyczna interpretacja polityki w marksizmie, Wydawnictwo PWN, Warszawa.

Korzeniowski, K. 1983. Podmiotowość człowieka. Metateoretyczne ramy teorii, [w:] Podmiotowość jednostki w koncepcjach psychologicznych i organizacyjnych, K. Korzeniowski, R. Zieliński, W. Daniecki (red.), Ossolineum, Wrocław-Warszawa-Kraków-Gdańsk, s. 9-75.

Kozłowski, S. 2015. Upodmiotowienie samorzadu lokalnego w okresie transformacji ustrojowej w Polsce, Dom Wydawniczy Elipsa, Warszawa.

Krakowiak-Drzewiecka, M. 2015. Skutki i perspektywy przeobrażeń komunikacji w środowisku lokalnym, [w:] Wspólnoty lokalne jako uczestnik i podmiot procesów transformacji gospodarczej, E. Zeman-Miszewska, A. Jakubowska, M. Krakowiak-Drzewiecka (red.), Wydawnictwo Uniwersytetu Ekonomicznego w Katowicach, Katowice, s. 57-72.

Krzemiński, I. 1992. Co się dzieje między ludźmi, Wydawnictwo Naukowe i Literackie Open, Warszawa.

Miczka-Pajestka, M. 2005. Podmiotowość czlowieka w perspektywie nowoczesnej techniki, Wydawnictwo Akademii Techniczno-Humanistycznej, Bielsko-Biała.

Nowak, A. 2011. Podmiot, system, nowoczesność, Wydawnictwo Naukowe Instytutu Filozofii UAM, Poznań.

Olejniczak-Szałowska, E. 2014. Prawo dostępu do informacji publicznej jako podstawa realizacji prawa do partycypacji społecznej w samorzadzie terytorialnym (zarys problemu), [w:] Partycypacja społeczna w samorzadzie terytorialnym, B. Dolnicki (red.), Wolters Kluwer Polska, Warszawa, s. 753-770.

Parnes, J. 2015. Internetowe media samorzadowe jako narzędzie dialogu władzy lokalnej z obywatelami, [w:] Przemiany mediów lokalnych i regionalnych, W. Furman, P. Kuca (red.), Wydawnictwo Uniwersytetu Rzeszowskiego, Rzeszów.

Regulski, J. 2010. Móc, umieć i chcieć. Ksztaltowanie samorządu terytorialnego w Polsce, [w:] Dwudziestolecie funkcjonowania samorzadu terytorialnego w Polsce, H. Kisiłowska, E. Malak (red.), Politechnika Warszawska, Warszawa, s. 15-19.

Regulski, J. 2000. Samorzad III Rzeczypospolitej. Koncepcje i realizacja, Wydawnictwo PWN, Warszawa.

Regulski, J. 2013. Samorządność i społeczeństwo obywatelskie - kilka pytań i wiele wątpliwości, „Samorząd Terytorialny", nr 3, s. 5-9,

Sartori, G. 1994. Teoria demokracji, Wydawnictwo PWN, Warszawa.

Starosta, P. 2012. Przynależność w dobie globalizacji, [w:] Tożsamość, nowoczesność, stereotypy, R. Dopierała, K. Kaźmierska (red.), Nomos, Kraków, s. 200-230.

Sura, R., Choma, R. 2014. Kilka spostrzeżeń na temat form partycypacji społecznej na poziomie gmin, [w:] Partycypacja społeczna w samorządzie terytorialnym, B. Dolnicki (red.), Wolters Kluwer Polska, Warszawa, s. 135-146.

Suwaj, P.J., Wenclik, M. 2009. Patologiczne konsekwencje nieuwzględnienia czynnika obywatelskiego w procesie decyzyjnym, [w:] Patologie w administracji publicznej, P. Suwaj, D. Kijowski (red.), Oficyna, Warszawa, s. 372-383.

Swianiewicz, P. 2012. Partycypacja społeczna $w$ realizacji polityk miejskich, [w:] Partycypacja obywateli i podmiotów obywatelskich w podejmowaniu rozstrzygnięć publicznych na poziomie lokalnym, M. Stec, M. Mączyński (red.), Wolters Kluwer Polska, Warszawa, s. 36-57.

Szostok, P., Rajczyk, R. 2013. Komunikowanie lokalne w Polsce. O instrumentach polityki komunikacyjnej samorzadów, Wydawnictwo Gnome, Katowice.

Szostok, P. 2017. Poczucie podmiotowości komunikacyjnej w samorządzie terytorialnym w Polsce, Wydawnictwo Adam Marszałek, Torun.

Turska-Kawa, A. 2011. Poczucie alienacji a użytkowanie mediów. W poszukiwaniu nowych zastosowań teorii użytkowania i gratyfikacji, Wydawnictwo Naukowe „Śląsk”, Katowice. 
Turska-Kawa, A. 2015. Determinanty chwiejności wyborczej, Wydawnictwo Uniwersytetu Śląskiego, Katowice.

Urban, O. 2008. Podmiotowość jednostki jako przedmiot badań nauk humanistycznych, Bogucki Wydawnictwo Naukowe, Poznań.

Weryński, P. 2012. Regionalne wzory partycypacji i typologie uczestnictwa, [w:] Zasoby lokalne jako dobro wspólne. Kapitat społeczny opolskich społeczności lokalnych, K. Postrzednik-Lotko, P. Weryński (red.), Warszawa, s. 27-72.

Wimmer, R., Dominick, J. 2008. Mass media. Metody badań, Wydawnictwo Uniwersytetu Jagiellońskiego, Kraków.

Wódz, J. 2004. Aktywność lokalna, obywatelstwo lokalne, polityka na szczeblu lokalnym, [w:] Samoorganizacja spoteczeństwa obywatelskiego: III sektor $i$ wspólnoty lokalne w jednoczacej się Europie, P. Gliński, B. Lewenstein, A. Siciński (red.), Instytut Socjologii i Filozofii PAN, Warszawa, s. 222-238.

\title{
THE IMPORTANCE OF A SENSE OF SUBJECTIVITY FOR SOCIAL ACTIVITY \\ IN THE LOCAL GOVERNMENT
}

\begin{abstract}
The article deals with the issue of the sense of communication subjectivity of citizens and their actual activity in the local environment. In the article, the author's concept of communication subjectivity was tested based on the questionnaire survey conducted on a sample of 500 respondents in 2016 in the Silesia district. The aim of the study was to analyze the sense of communication subjectivity and the way it indicates the activity of citizens in the local environment. The central hypothesis of the study was as follows: the sense of subjectivity is associated with activity in the local government. The author characterizes the phenomenon of subjectivity at the local level and pays attention to the difference between the sense of general and communicative subjectivity. Then she discusses the results referring to the meaning of the sense of communication subjectivity for civic activity and draws the conclusions. Empirical findings confirm that communication activity correlates with actual activity in the local environment, especially the aspects of communication subjectivity associated with two-way communication. The study showed a low level of the sense of communication subjectivity, which indicates the reasons for the low activity of citizens in the local environment. Moreover, the results reveal that the development of self-government communication activities should lead to encouraging active participation in communication processes and building a reasonable belief in them as far as the importance and the effectiveness of these activities are concerned.
\end{abstract}

Keywords: social activity, local government communication, social participation, communication subjectivity

\section{BIOGRAM}

Patrycja Elżbieta Szostok-Nowacka, badaczka komunikacji lokalnej, w szczególności samorządowej. Interesuje się psychologicznymi aspektami komunikowania na różnych poziomach, potencjalnym i realnym wpływem mediów. Zorientowana na badania empiryczne, w szczególności oparte na analizie zawartości mediów oraz badania społecznego odbioru różnych aspektów komunikowania. Za książkę Poczucie podmiotowości komunikacyjnej w samorządzie terytorialnym w Polsce wyróżniona I nagrodą w konkursie im. Czesława Mojsiewicza na najlepszą książkę politologiczną. 